\title{
An Investigation of the Motives and Purchase Intentions of Malaysian Consumers on Taiwan Wedding Photography Tourism Products
}

\author{
Wan-Yu Chang \\ Department of Tourism and MICE Management \\ Chung Hua University \\ Hsinchu City, Taiwan, R.O.C \\ wchang@chu.edu.tw
}

\begin{abstract}
In line with the "New Southbound policy" of the current administration, this study, aiming at people from Southeast Asia, will focus on Malaysians as research subjects, for the close tourist interaction between the two countries. The purchase motive, purchase intention, correlation, and statistics of Malaysian consumers on wedding photography products in Taiwan will be studied. Data will be collected for statistical analyses, including descriptive statistics, factor analysis, ANOVA, correlation analysis, as well as regression, and to examine the hypotheses in this research. Furthermore, suggestions, based on research findings, will be made to the government, the industry, and future researchers.
\end{abstract}

Keywords-theme tour; pre-wedding photography tour; purchase motive; purchase intention; consumer behavior

\section{INTRODUCTION}

Taiwan has the reputation as a "Kingdom of Wedding Dresses". It provides $70 \%$ of wedding dresses in the global market. From the upstream accessories, dress fabric to the downstream dress finished, and even branding, the output value account for the first in the world. Taiwanese wedding service has become an all-inclusive wedding industry. Including photography, wedding dresses, cosmetics and styling, as well as extra wedding gowns, the service package has kept improving. In addition, the tourist spots for wedding photography are highly diverse, along with convenient transportation and affordable pricing. Therefore, many overseas newlyweds are attracted, especially those from Singapore, Malaysia, Hong Kong, Macao, Japan, Mainland China, Korea, etc. For these places, tourist groups to Taiwan for wedding photography are getting popular.

\section{RESEARCH BACKGROUND}

\section{A. The market of wedding photography in Taiwan}

According to Taiwan Tourism (2009), published by Taiwan Visitors Association, it is estimated that foreign newlyweds visiting Taiwan for wedding photography have rapidly increasing, from 250 couples per month in 2008 to 500 couples per month at most. In that figure, visitors from Hong
Kong have a share of more than $50 \%$ (Lai, 2012). An announcement made by Mr. Xi-Lin Liu, the Deputy Director of the Tourism Bureau, saying that there are two major goals for the promotion of foreign newlyweds' visiting Taiwan: the first is to facilitate the development of wedding service industry in Taiwan, and the second is to attract foreign visitors with the unique charm of Taiwan. There are unparalleled mountain and sea scenes in Taiwan, which could attract youth from Mainland, Hong Kong, Macao, and Southeast Asia for wedding photography here. In addition, by combining wedding cakes, wedding parties, and honeymoon tours together, an all-connected shopping service for wedding could be provided. Besides, Mr. Liu also plans to promote wedding services with Taiwanese features, e.g., aboriginal weddings in the east coast, diving weddings in Green Island, etc. And for Sun Moon Lake, a must-see for tourists from Mainland, there is also a special wedding service available in the paper chapel (Lin, 2013). In 2013, the Tourism Bureau promoted "The touring plan for wedding", targeting on population in the Mainland and Southeast Asia. Micro movies were produced and played overseas to recommend popular wedding photography sites to the newlyweds. At the same time, manuals were designed to introduce the wedding service industry. With the all-connected service provided, foreign newlyweds can find the information they need and have all the wedding planning and details taken care of, including group touring in Taiwan for the relatives and friends. According to the statistic figures provided by the Tourism Bureau, the market share of such wedding services for foreigners has been increasing annually, from 100 couples per month in 2008 to more than 400 couples per month in 2012. With more than 5000 couples from overseas visiting for wedding photography per year, this is an emerging market with a great potential.

According to the wedding industry, a package of wedding photography service asks for NT\$ 40000 and up. Assuming a five-day stay in Taiwan, a newlywed couple would bring in a value of NT\$150000. With 5000 couples per year, this makes a business of 750 million dollars (Lin, 2013). The service providers in Taiwan are known in Asia for the professional 
skills, efficient picture-selection, as well as privileged price. Many foreign visitors plan a tour for both wedding photography and sightseeing, and they would be able to bring back with them finished wedding photos at the end of their tour. For them, the cost for both sightseeing and wedding photography in Taiwan roughly equals to the cost of wedding photography alone in their own countries. Such innovative traveling packages of combining both tourist industry and wedding industry have become popular in Southeast Asia. In recent years, such a trend has brought Malaysian visitors for both wedding photography and portrait photography.

The wedding photography industry in Taiwan has been at the mature phase. The price is reasonable, and the high-quality service is very efficient. And the visit of foreigners for wedding photography will bring in big market value in tourism. Nonetheless, there has been only limited research on wedding photography tours. This study will then focus on the target population from Southeast Asia and their consuming features of taking part in wedding photography tours in Taiwan. The goal is to identify the purchase motives and purchase intention of target consumers. And by knowing the consumers, the innovation and renovation of touring products would be possible through discussion on marketing, photography design, marketing policy, customer-service patterns, and organization and process reengineering. The promotion of service quality of touring in Taiwan and the formation of specialties of touring in Taiwan are within the directions of discussion in this research.

\section{B. Research purpose}

According to the background to this study, it is shown that wedding photography touring is a highly individualized theme tourist product. With the matured development of wedding industry in Taiwan, this could be another marketing point for tourism in Taiwan, which comes with a great potential. In other words, it would help to promote the development of Taiwanese tourism in a specialized marketing approach, by figuring out the characteristics of target foreign tourists' consuming on wedding photography touring, i.e., the purchasing motives and intention of foreign consumers on wedding photography tourist products, and finding out the key factors attracting foreign visitors to Taiwan for wedding photography tours, and then to develop more wedding photography touring products and packages, more wedding photography attractions, and custom-made wedding photography activities.

This study, focusing on people from Southeast Asia, takes Malaysians as main subjects, which have close interaction with Taiwan. The study intends to investigate factors impacting the purchase motives and intention of Malaysian consumers' selection of wedding photography touring products, from the perspective of consumers. The research purpose could be listed as the following three points: First, the key factors influencing Malaysian consumers' purchase of wedding photography touring products. Second, to examine if the purchase motives of Malaysian consumers' purchasing wedding photography touring products will influence their purchase intention. Third, to explore the differences of motives and intention among consumers of wedding photography touring products via demographic statistical variables. Based on the research findings, effective marketing suggestions could be provided to the government, the wedding photography industry, and the tourist agency, for promoting such wedding photography products and services and for encouraging the consumers to carry their ideas of overseas wedding photography tours into actions.

\section{LITERATURE REVIEW}

In Taiwan, more than $90 \%$ of newlyweds would go for wedding photography. This is like already an essential part of wedding custom in Taiwan. In the West and Japan, the newlyweds take pictures only at the time of wedding events. Nonetheless, wedding photography has become an industry in Taiwan. The newlyweds would take pictures in advance. In addition, they do not only take pictures way before the wedding events, but also shoot pictures in themes, with a complete package of wedding gowns, photography, cosmetics and styling provided (Lee, 2003). Unlike providing such services respectively overseas, the wedding industry in Taiwan began combining cosmetics, wedding dressing, and photography service together as early as in the 1970s, and then created the world's only "three-in-one" wedding photography. Such service soon disseminated all over Taiwan, and then also spread to other Chinese areas (Yu, 2011). After the 90s, the amount of wedding photography stores increased quickly and the market reached the phase of intense competition. In order to offer full service and save the time and efforts for wedding preparation from shopping at different stores and serviceproviders, the integrated wedding photography service (a package) became the mainstream. Such a package included styling, wedding dresses, photography, as well as other wedding appliances such as flowers, signature silk, decorated photo albums, wedding favor cards, etc. (Lin, 2012). The peripheral industry got promoted as well, like photo printing, frames and albums, publishing (wedding cards), gownmaking, bride make-ups, beauty and styling, flower service (bouquets, car decoration, hall arrangement), wedding cakes, wedding candy, honeymoon trips, and wedding consulting, etc. (Fu, 2015). Obviously the wedding service industry in Taiwan has a significant scale of business. And what can't be ignored here is that the development of wedding photography in Taiwan is considered ahead of the world, both the service level and photography skills are well-known internationally. Professionals from Korea, Mainland China, Singapore, Malaysia, Japan, etc. often come in groups to observe and learn like styling, packaged service, and demonstration of photographic skills. In 2011, Japan's NHK even produced a thematic program on the unique wedding photography culture in Taiwan (Lin, 2012). Lin (2012) also commented that because the wedding photography service in Taiwan owns features of a good level of skills, low cost, creativity, and oneon-one costumed service, many newlyweds from Hong Kong, Mainland China, and surround Southeast Asia countries would come to Taiwan for both touring visit and wedding photography. 


\section{A. Wedding photography tour}

Doing wedding photography has seemed to become a unique, unofficial cultural pattern in Taiwan. Many newlyweds consider wedding photography an essential part of the wedding preparation. This has influenced surrounding Southeast Asian countries like Singapore, Malaysia, Hong Kong, etc., and also significantly influenced Mainland China, which shares the same cultural background. Therefore, many local governments begins aggressively to construct the "happy wedding industry", which is believed to be able to promote local business, boost tourism, and demonstrate the Taiwanese cultural power. The Tourism Bureau (2011), in the project "Tour Taiwan Years 2008-2009", stressed on developing diverse tourist products, in which "salon photography and honeymoon trip" is considered to be an effective tool for Taiwan tourism. The theme "wedding photography tourism" thus emerged. As a new form of touring, wedding photography centers on shooting wedding-themed pictures yet accompanies packaged touring activities. That is a custommade, theme tourist product. Chiang (2016) defined wedding photography tourism as the combination of wedding photography and sight-seeing touring.

Li (2009) categorized wedding photography tourism in theme touring products, which is a custom-made touring activity offered to consumers to meet their special needs. Fang (2013) pointed out that tourists joining theme tours expects the self-realization experience from intense interaction with local society, culture and environment. In Fang's study, features of theme touring are: I) the program of a theme tour centers on the needs and preferences of the tourists; II) personal values and life styles would influence the traveling program; III) theme touring can enhance the psychology and functioning benefits of the tourists; IV) theme touring can enrich the knowledge and value of the tourists; V) theme touring applies to smaller groups, and serves custom-made theme touring programs; VI) theme touring can satisfy the tourists' seeking for new knowledge and fulfill their wishes. Li (2009) defined wedding photography tourism as a touring program centered on wedding photography with specified themes, in which only one-to-two days during the trip would be spent on wedding photography.

Chang (2011) defined wedding photography touring products as theme-tour products that combining wedding photography and tourist activities. Wu and Lai (2012) mentioned in their study that wedding photography tourism is "the newlyweds traveling to areas outside of their residence for multiple days for touring programs combining sight-seeing and wedding photography, which includes wedding dresses, cosmetics and hair-styling, negotiation of photographic style and cost, indoor and outdoor shooting, and photo selection." Fang (2013) also considered wedding photography tourism is a kind of thematic tourism, which is designed to meet the special needs of newlyweds by combining tourism and wedding photography, and is type of tourism covering both shooting of wedding photograph and sight-seeing. Based on the definitions provided by abovementioned researchers, wedding touring is more precisely labeled "wedding photography tourism" in this study, and is defined as: the newlyweds choose to visit areas outside of their residence area for thematic activities, centered on wedding photography, along with multiple-day touring programs including touring experiences. For wedding photography tourism, the newlyweds choose their favorite tourist destination and buy the wedding photography package including wedding dresses, photography, and styling. This is a thematic tourist product featured with individualized characteristics.

The features of wedding photography tourism are that the sites for photograph-shooting are usually away from their hometowns and are mainly natural settings, unique and highly relevant to the newlyweds, or places with exotic-flavored scenes and cultures. When the newlyweds are doing wedding photography, they can also experience local cultural, custom, and scenic characteristics. That is a tourist product of commemoration, practicality, and artistry.

\section{B. Purchase motives}

Motive is a personal, internal drive (Carlson \& O'Cass, 2010). Motive is an internal effect that initiates the personal activity, maintains that activity, and drives that activity toward a certain target. It is the inner drive that forces the individual to a variety of behaviors (Carlson \& O'Cass, 2010). Chen et al. (2012) believed that motive is a stimulated need. Emarketer (2010) stated that motive is an internal drive that makes the subject takes action when there is the tension triggered by dissatisfaction of needs. Kim et al. (2011) thought that motive is an activated need. Liao et al. (2012) pointed out that motive is the reason that makes individuals take actions. Lu et al. (2010) said that motivation is a state in which people will perform adaptive behaviors to options of expected goals. Wu et al. (2010) defined purchase motive as consumer's drive caused by rational and emotional needs. Arnold and Reynolds (2003) explored consumers' purchase motivation from the hedonic perspective and concluded that there are six shopping motivations:

(1) Adventure shopping: shopping for stimulation, adventure, and the feeling of being in another world.

(2) Social shopping: the enjoyment of shopping with friends and family, socializing while shopping.

(3) Gratification shopping: shopping for stress relief, shopping for relaxation.

(4) Idea shopping: shopping to keep up with trends and new fashions, and to see new products and innovations.

(5) Role shopping: shopping for enjoyment.

(6) Value shopping: shopping for sales, looking for discounts, and hunting for bargains.

Lou, Tsai, Pan, and Bie (2003) pointed out that shopping motivation is shaped by multiple factors.

Consumers' purchase motivations consist of product motivation (including rational and emotional motives) and 
customer motivation (referring to motives that bring the consumers back to the same shop for buying). Lou et al. (2013) further categorized in details the purchase motivations (Yang, 2014):

1. Emotional motivation:

(1) Pride: goods that satisfy personal pride, like brand-name products.

(2) Emulousness: what purchased, the quality, or the price, etc. having to exceed others to gratify the self.

(3) Desire to sample new things: to be proud of getting the up-to-date products to attract others' attention.

(4) Desire for comfort: buying the best products for the comfort and pleasure of the self and the family.

(5) Desire for entertainment: buying the up-to-date electrical or $3 \mathrm{C}$ products for enjoying the life.

(6) Gratification of senses: buying goods for the gratification of senses of the visual, the auditory, or the taste, etc.

(7) Sense of security: to buy products to assure safety of life, like insurances, nutrient supplementary, etc.

(8) Curiosity: to meet the desire of curiosity or mystery.

(9) Sense of possession: to take ownership as the goal, not caring whether the products being useful or not. Gratification comes from possession.

(10) Special preference: to buy in order to meet the special preferences of the self.

2. Rational motivation:

(1) Convenience: goods which are easy to use and easily accepted by customers, like delicate, handful tools.

(2) Enhancement of efficiency: tools and equipment used to increase efficiency.

(3) Safety and reliability: products to be reliable; high quality.

(4) Good service: products with good and accountable after-sales service.

(5) Durability: products to be durable; not easily damaged.

(6) Economy: for products with high princess.

3. Patronizational motivation:

(1) Convenient locations.
(2) Extended business hours.

(3) A wide variety of goods and products.

(4) High quality.

(5) The shop attendants are polite and well-trained.

(6) Good business reputation.

(7) Offering credits and extra services.

(8) Prices to be appropriate.

(9) For matching, or showing off, one's special identity.

In sum, for evaluating purchase motives, the consumption motive theory proposed by Lou et al. (2003) matches better to this study on investigating the internal drives of consumes on wedding photography products. In this study, Malaysians are chosen to be research subjects. From the perspective of consumers, this study is to discuss how purchase motives would influence consumers' selection of Taiwanese wedding photography products. As the study to be based on the consumption motive theory (Lou et al., 2003), the three constructs: (1) emotional motivation, (2) rational motivation, and (3) patronizational motivation; have constituted the evaluation framework for this study. After certain adaptation, an assessment matching the research topics would be developed.

\section{Purchase intention}

Zeithaml (1988) believed that consumers' purchase intention will be influenced by the objective price, product feature, perceived quality, and perceived value. In this case, consumers' purchase intention is composed of consumers' evaluation or attitude to the products and external factors. Nonetheless, purchase intention is one of the willingness. Many studies have confirmed that purchase intention is categorized as part of the consumers' willingness (Ellen \& Mark, 1999). Doddest et al. (1991) thought that purchase willingness is the possibility of the consumer's willing to buy a certain product. Morwitz and Schmittlen (1992) pointed out that in marketing research, purchase intention is usually used to predict the purchase behaviors. In Kotler's (2003) research, there are two factors influencing purchase intention: (1) others' attitudes, which include others' preferences for the selves and following others' expectations; and (2) situational factors, which would be involved in changing consumers' purchase intention unpredictably, which is originally composed of personal income, predicted price, and predicted profits. Schiffman and Kanuk (2004) pointed out that purchase willingness is applied to calculate the possibility of a consumer's buying a certain product. The higher the purchase willingness is, the bigger the chance of actually buying will be. Consumers reflecting positive purchase willingness will form a positive promise. Spears and Singh (2004) thought that purchase willingness is a personal plan for buying some product. Here "purchase willingness" refers to the consumer's buying behavior after evaluating the whole product. That is a 
perceptual response for taking certain action toward the target. Chang (2011) categorized the perceptual value that influences the purchase intention on wedding photography products into four constructs: service quality, reasonable price, perceived pleasure, and perceived novelty. The results showed that all the four constructs are significantly related to perceptual value, and the correlation between perceptual value and the purchase intention on wedding photography products is also highly significant.

Based on above discussion on purchase intention, this study will, on the basis of Chang's (2011) constructs, apply the six constructs: service quality, trust, brand popularity, price, perceived pleasure, and perceived novelty; to the assessment of purchase intention on wedding photography products. The above-mentioned constructs of purchase intention on wedding photography products are explained as follows:

1. Service quality: Zeithaml, Parasuraman, and Berry (1990) proposed that service quality could apply onto the tourism service industry, and could be evaluated via quantitative methods. Berry and Parasuraman (1991) identified five attributes that influence service quality, which are:

(1) Physical: stimuli from service facilities, equipment, personnel, service items, etc.

(2) Reliability: the ability to fulfill the promised quality accurately.

(3) Responsiveness: be willing to help customers actively and able to offer service quickly.

(4) Guarantee: service personnel with politeness and profession, being able to win customers' trust.

(5) Empathy: being abler to care about customers with empathy.

Wedding photography products, as one of the tourist activities, share features with service industry. Therefore, in this study, the above-mentioned five constructs would factor in the evaluation for the customers' perceived values.

2. Trust: Trust means that a consumer is happy and happy to expect a certain act from the shop, and that act is important to the consumer (Gierl \& Huettl, 2010). Consumers take higher risks when conducting overseas deals, comparing to traditional shopping (Carson \& O'Cass, 2010). In such conditions of uncertainty and high-risk, trust would not only become a very important factor (Kim et al., 2010), but also the foundation of decision-making whether consumers will purchase the wedding photography products or not.

3. Brand popularity: American Marketing Association defines "brand" as a name, a sign, an item, a symbol, a design, or the combination of these. It could be used to identify the seller's service or products, and to be distinguished from the competitors' services or products.
4. Price: Sweeny, Soutar, and Johnson (1998) found in their study about perceived value of products that among constructs affecting perceived value, price works as a major factor affecting consumers' purchase decisionmaking. For wedding photography products, as multiple items contained in the package, the price would be relatively higher than ordinary tourism products. In addition, many consumers would first consider price as an evaluation index when they purchase. Therefore, the price of tourism products would be a very important factor in discussion of consumers' purchase intention.

5. Perceived pleasure: Chang (2011) found that when consumers take tourism activities, they usually want to gain feelings of enjoyment, happiness, and pleasure. The perceived joy and fun after the consumers purchase wedding photography products would affect their perceived value on wedding photography products.

6. Perceived novelty: Wedding photography activities are usually once-in-a-lifetime experiences. For consumers, they would gain sense of novelty, freshness, and being different from the others. Chang (2011) reported that attending wedding photography activities made consumers feel like doing something new and different from past experiences. They also felt surprised and excited in such activities, which were very different from their life experience in the past. For consumers, they would weigh heavily on the perceived values of perceived novelty.

This study targets on Malaysians as research subjects and tries to investigate, from consumers' perspective, how tourist motives would affect purchase intention on consumption of wedding photography products in Taiwan. Chang's (2011) research framework is used in this study to develop the six constructs: (1) service quality, (2) trust, (3) brand popularity, (4) price, (5) perceived pleasure, and (6) perceived novelty. The constructs are applied to the evaluation of purchase intention for Malaysian consumers' buying wedding photography products in Taiwan in this study.

\section{RESEARCH METHODOLOGY}

This study aims at applying the effects of purchase motives onto purchase intention on wedding photography tourism, trying to identify important factors that influence consumers' shopping of wedding photography products. According to the research purpose and literature, the following research hypotheses are proposed:

\section{A. Research hypotheses}

H1: The emotional motivation of wedding photography shopping has a significant positive effect on the purchase intention.

$\mathrm{H} 2$ : The rational motivation of wedding photography shopping has a significant positive effect on the purchase intention. 
H3: The patronizational motivation of wedding photography shopping has a significant positive effect on the purchase intention.

H4: The correlation between purchase motives of wedding photography service and the purchase intention varies significantly according to the variation of demographic statistic variables.

\section{B. Research Framework}

This paper will apply the survey-styled empirical study to examine the research framework as Figure 1.

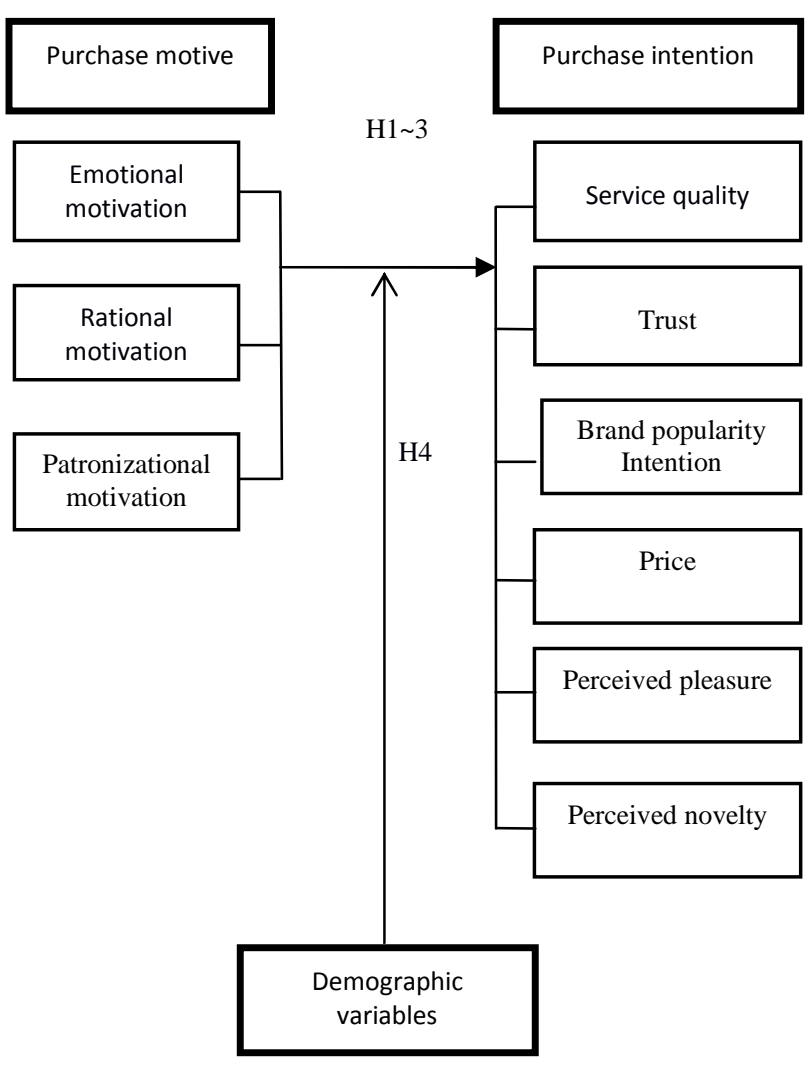

Figure 1 Research framework

\section{Research subjects}

According to previous literature review and the "New Southbound Policy" (2016) of the current administration, the study focuses on people from Southeast Asian countries. Malaysians, who have close interaction with Taiwan, are selected as major research subjects. Target subjects are between eighteen to thirty-five years old. The preliminary test is scheduled between August 1st to September 1st, 2017. Official survey administration is scheduled between September 15 th to December 31 st. The survey will be released on Internet media like forums and social community websites in Malaysia, and research data will be collected on-line for empirical analysis.

\section{Measurement tool}

The measurement tool is a questionnaire developed on the basis of literature review, and is examined for the validity and reliability. The content of the questionnaire includes personal demographic data, purchase motivation and purchase intention on wedding photography tourist products. The questionnaire is verifies by five experts, who are from educational specialty, wedding photography business, and photography professionals, etc., for checking expert validity. Higher scores mean stronger consent on that item. The original Chinese questionnaire will be then translated into English, and will be conducted on thirty participants for preliminary test. The finalized questionnaire, after preliminary examination, will become the official questionnaire.

\section{E. Analysis approach}

This study applies factor analysis and reliability analysis for examining questionnaire items' validity and reliability, and regression analysis for understanding the effects of touring motives on purchase intention. Furthermore, ANOVA is applied to reveal the effects of demographic variables on the correlations of touring motivation and purchase intention.

\section{F. Estimated contribution}

This study aims at discussing "purchase motives and purchase intention influencing Malaysian consumers' purchase of wedding photography products. The results will be applicable on implement of marketing and promotion plans for wedding photography industry, to enhance the sale performance of wedding photography touring products in tourism and leisure industry as well as the industrial competitively of tourism and leisure industry.

The results of this research will hopefully help the business understand the important factors in consumers' buying of wedding photography touring products. The results could be applied on marketing strategies, and could lead to future studies for researchers.

It is expected to further understand the decision-making for purchase of wedding photography tours in Taiwan by Southeast Asians and the current condition of wedding photography industry. Therefore, the application of professional knowledge could be enhanced, the research ability to be promoted, and further research to be extended in related fields.

\section{References}

[1] Executive Yuan, R.O.C. (2016). 2017 Administrative Policy. Retrieved from:file:///C:/Users/Nicole/Downloads/106\%E6\%96\%BD\%E6\%94\%B F\%E6\%96\%B9\%E9\%87\%9D.pdf

[2] Taiwan Visitors Association. "Love 101"project promotes honeymoon wedding tourism marketing in Taiwan. Taiwan Tourism Bimonthly Publication (Chinese version), 2009, Vol.512, p14-15. Retrieved from: file:///C:/Users/Nicole/Downloads/512\%20taiwanM.pdf

[3] Lai, M. H. The Study of Bridal Photography Tourism Marketing Strategy in Taiwan. Unpublished Master's Thesis, Graduate Institute of Hospitality, National Kaohsiung University of Hospitality and Tourism, 2012 
[4] Lin, S. H. Taiwan Tourism Bureau promotes wedding travel. 2013. Retrieved from: http://www.chinatimes.com/newspapers/20131020000027-260202

[5] Yu Ying Lee (2003b) The Bride Maker: The Formation of Bridal Industry in Contemporary Taiwan, paper presented in SASE 2003: Knowledge, Education, and Future societies, 15th Annual Meeting on Socio-Economics LEST (Laboratoire d'Economie et de Sociologie du Travail) Aix-en-Provence, France, 26 - 28 June, 2003.

[6] Yu, Y. C., Chan, Y.W., Hsiao, C.C., Yang, T.Y., and Chen, S.Y. Service process report of Taiwan innovational wedding industry - the common growth of wedding photography and wedding consultants. Unpublished Master's Thesis, Department of Business Management, National Sun Yat-sen University, Taiwan, 2011

[7] Lin, Y.W. Dream come true--Schema \& Behavior of Purchasing Wedding Photography. Unpublished Master's Thesis, Institute of Publishing \& Cultural Enterprise Management Studies, Nan Hua University, Taiwan, 2012.

[8] Fu, J.C. Introduction to Wedding Style Planning. Yang-Chih Book Co., Ltd. 2015.

[9] Taiwan Tourism Bureau Executive information System "Tour Taiwan Years 2008-2009 Plan". 2011. Retrieved from: http://admin.taiwan.net.tw/upload/contentFile/201608/20081103_1.pdf.

[10] Chiang, H. L. A Study of Foreign Travelers' Motivation and Tourism Attraction of Taiwanese Bridal Photography Tourism. Unpublished Master's Thesis, Department of Tourism, Providence University, Taiwan, 2016

[11] Li, P.Y. Brand Alliance to Tourist's Perceived Risk and Purchase Intention: Evidence from Bridal Photography Tourism. Unpublished Master's Thesis, Graduate Institute of Recreation, Tourism, and Hospitality Management, National Chiayi University, Taiwan, 2009.

[12] Chang, H. F. Exploring the factors affecting consumers' intentions to purchase wedding photography tourism products- Insight from a perceived value perspective. Unpublished Master's Thesis, Department of Business Administration, Chung Hua University, Taiwan, 2011.

[13] Wu, W. C. and Lai, M. H. The study of special interest tourism marketing strategy-in case of bridal photography tourism. Paper presented in 2012 The 4th Asia Pacific Alliance on Tourism and Hospitality Education \& The 12th Annual Conference in Hospitality \& Tourism.

[14] Fang, W.M. The Study of the Critical Success Factor in Taiwan Bridal Photography Tourism. Unpublished Master's Thesis, Graduate Institute of Travel and Tourism Management, National Kaohsiung University of Hospitality and Tourism, 2013.

[15] Carlson, J., and O'Cass, A. Exploring the relationships between eservice quality, satisfaction, attitudes and behaviours in content-driven e-service web sites. Journal of Services Marketing, 24(2), 112-127, 2010

[16] Chen, H., Papazafeiropoulou, A., Chen, T. K., \&; Hsiu-Wen, L. Commercial exploitation of facebook: How companies adopt facebook as a marketing tool. Retrieved from ECIS 2012 Proceedings, 2012. Web Site: http://aisel.aisnet.org/ecis2012/7

[17] Emarketer. Social network ad spending to approach $\$ 1.7$ billion this year. 2010. Retrieved from eMarketer, Web site: http://www.emarketer.com/Article.aspx?R=1007869

[18] Kim, H. W., Gupta, S., \& Koh, J. Investigating the intention to purchase digital items in social networking communities: A customer value perspective. Information \&; Management, 48 (6), 228-234, 2011.
[19] Liao, S., Chu, P., Chen, Y., \& Chang, C. C. Mining customer knowledge for exploring online group buying behavior. Expert Systems with Applications, 39 (3), 3708-3716, 2012 .

[20] Lu, Y., Zhao, L., \& Wang, B. From virtual community members to $\mathrm{C} 2 \mathrm{Ce}-\mathrm{Commerce}$ buyers: Trust in virtual communities and its effect on consumers purchase intention. Electronic Commerce Research and Applications, 9(4), pp.346-360, 2010.

[21] Wu, J. J., Chen, Y. H., \&; Chung, Y. S. Trust factors influencing virtual community members: a study of transaction communities. Journal of Business Research, 63 (9/10), 1025-32, 2010.

[22] Arnold, M. J., \& Reynolds, K. E. Hedonic shopping motivations. Journal of retailing, 79(2), 77-95, 2003.

[23] Lou, Y. C., Tsai, T. C., Pan, C. W., and Bie, L. T. (2003). Consumer Behavior. Department of Transportation and Communication Management Science, National Open University.

[24] Yang, S. Y. The Effect of Buying Motives, Situational Factors, and Visitor Experience on Purchase Intention -The Case of Souvenir at Chihsing Tan Katsuo museum. Unpublished Master's Thesis, Department of Agribusiness Management, National Pingtung University of Science and Technology, Taiwan, 2014.

[25] Zeithaml, V. A. Consumer Perceptions of Price, Quality, and Value: A Means-End Model and Synthesis of Evidence. Journal of Marketing, 52(3): 2-22, 1988

[26] Ellen G, and Mark J. S. The Different Roles of Satisfaction, Trust, and Commitment in Customer Relationships. Journal of Marketing, Vol.63, Apr., p70-87, 1999.

[27] Dodds, B. W., Monroe, K. B., \& Grewal, D. Effects of Price, Bands and Store Information on Buyers' Product Evaluation, Journal of Marketing Research, Vol.28, No.3, 308-319, 1991.

[28] Morwitz, V. G., \& Schmittlein, D. Using segmentation to improve sales forecasts based on purchase intent: Which "intenders" actually buy? Journal of Marketing Research, 29(4), 391-405, 1992.

[29] Kotler, P. Marketing management (11th ed.). New Jersey: Prentice Hall, 2003.

[30] Schiffman, L. G., and Kanuk, L. L. Consumer behavior, 8, N.J.: Pearson Education Inc., Upper Saddle River, New Jersey: Prentice-Hall, 2004.

[31] Spears, N. and Singh, S. N., Measuring attitude toward the brand and purchase intentions. Journal of Current Issues and Research in Advertising, Vol.26, No.2, pp. 53-66, 2004.

[32] Zeithaml, V., Parasuraman, A., \& Berry, L.L. Delivering Quality Service. New York: The Free Press, 1990.

[33] Berry, L. L. \& Parasuraman, A. Marketing service. New York: The Free Press, 1991.

[34] Gierl, H., \&; Huettl, V. Are scarce products always more attractive? The interaction of different types of scarcity signals with products' suitability for conspicuous consumption. International Journal of Research in Marketing, 27 (3), 225-235, 2010.

[35] Kim, J. U., Kim, W. J., \& Park, S. C. Consumer perceptions on web advertisements and motivation factors to purchase in the online shopping. Computers in Human Behavior, 26, 1208-1222, 2010.

[36] Sweeney, J. C., Soutar, G. N., \& Johnson, L. W. The impact of purchase involvement on the quality-value relationship. In Proceedings of the Australian and New Zealand Marketing Academy Conference, University of Otago, Dunedin, 1998.

[37] Executive Yuan, R.O.C. 2016 New Southbound Policy Promotion Plan. Retrieved from: file:///C:/Users/Nicole/Downloads/50f0a410-026c433e-850d-b88fe0384d17\%20(2).pdf 